\title{
Comparison of silk fabric dynamic drapability and correlation analysis of impact factors
}

\author{
DOI: $10.35530 / I T .071 .01 .1536$
}

\author{
XINRONG HU \\ TAO PENG \\ JUNPING LIU \\ GANG LI \\ SHUQIN CUI
}

JUNJIE ZHANG

RUHAN HE

MIN LI

JIA CHEN

\section{ABSTRACT - REZUMAT}

\section{Comparison of silk fabric dynamic drapability and correlation analysis of impact factors}

Drapability is the unique performance that allows the fabric to be bent in multiple directions. Silk fabric has well hand feeling and draping property, it is suitable for studying the dynamic drape performance of fabric. In this paper, we select 15 different samples of silk fabrics to measure its structural characteristics, mechanical properties and drape characteristics for studying the impact factors of dynamic draping property about silk fabric. A correlation analysis is made with the measured fabric parameters to get the factors sequence which mainly affects the dynamic draping property of fabric. Experimental result shows that the draping property of silk fabric is affected by many performance parameters, however, the latitudinal tensile is the biggest impact factor among all these parameters.

Keywords: dynamic drape; correlation analysis; silk; impact factor; fabric performance parameters

\section{Analiza drapajului dinamic al țesăturilor din mătase naturală și a corelației factorilor de impact}

Drapajul reprezintă proprietatea care permite îndoirea țesăturii în mai multe direcții. Țesătura din mătase naturală prezintă tușeu și drapaj corespunzătoare pentru studierea drapajului dinamic. În această lucrare, au fost selectate 15 probe diferite de țesături din mătase naturală, pentru a determina caracteristicile structurale, proprietățile mecanice și caracteristicile de drapaj ale acestora, în scopul studierii factorilor de impact ai drapajului dinamic. Analiza de corelație a fost efectuată utilizând parametrii țesăturii pentru a determina factorii care influențează, în principal, drapajul dinamic. Rezultatele experimentale au arătat că drapajul țesăturii din mătase naturală este influențat de o multitudine de parametri de performanță, însă, rezistența la tracțiunea este cel mai important factor de impact.

Cuvinte-cheie: drapaj dinamic, analiză de corelație, mătase naturală, factor de impact, parametrii de performanță ai țesăturii

\section{INTRODUCTION}

Fabric draping performance refers to the degree and forms of fabric draping under its own weight, which refers to the degree and the form of fabric draping that are resulted by the gravity of the fabric. It is an important index to evaluate the fabric hand feeling, appearance, quality and the 3D forms. According to the fabric of the state, the draping state of fabric can be divided into static draping and dynamic draping. The static draping describes the natural state of the fabric affected only by gravity, the dynamic draping describes the motion state of the fabric caused by the external forces. Due to the dynamic draping of the fabric is greatly affected by many factors of the fabric, such as performance parameters, the material quality, the structure, the weaving method, and etc. Even the methods which measuring the parameters also will lead to the different draping results. Excellent measuring methods and evaluation indexes have great meanings for the textile industry. In recent years, many scholars focus on how to evaluate draping performance of the fabric and have done some related researches. Some scholars [1] propose the improvement methods of the simulation models by the original parameters, some scholars [2] propose methods to improve the measurement method to get more accurate parameters. However, few scholars study the impact factors of the fabric draping performance. Guo Hongxia [3] do some research to compare the drapability of the bamboo knitted fabric and discuss the correlation of its influencing factors. It is only qualitatively analysed the draping property of the bamboo knitted fabric, but lacked quantitative analysis.

Silk fabric has a well hand feel and draping performance with good moisture and health care function, it is the common fabrics on the market. In order to describe the fabric under the motion state of draping and the 3D simulation for the movement of the fabric, we take the silk fabric as an example and select 15 kinds of silk fabrics to evaluate and analyse all the parameters which probably influence the dynamic draping of silk fabric. These parameters include the fabric structural parameters, mechanical performance 
parameters, physical performance parameters and other parameters. In this paper, we want to obtain the most important impact factors which influence the dynamic draping performance of the silk fabric.

\section{PARAMETERS MEASUREMENT OF SILK FABRIC}

\section{Fabric structural characteristics parameters}

In order to compare the differences of the silk fabric drape [3], we selected 15 kinds of silk fabrics which are made of $100 \%$ mulberry silk. They include Jianhong crepe, Fancy crepe georgette, Silk spinning, Silk taffeta, Habotai, Silk twill, Double palace, Plain crepe, Crepe de chine, Pearl satin, Shun weft satin, Heavy crepe, Sangbo satin, Spun silk, Hangluo. We number the fabric from 1 to 15 and get its basic structural parameters as shown in table 1

From the sample fabric structure above, we can classify the materials into three categories, including plain, twill and satin [4]. No. 5 fabric Hangluo is the unit of plain with gauze organization.

From the perspective of the twisting properties of fabric sample, No. 1, No. 3, No. 6, No.13 and No.14 are crepe weave fabric, warp wire not twisting or weak twisting, weft wire used two left two right strong twisting, the overall presentation crepe effect of fabric. No. 2, No. 8 and No. 15 belongs to the spinning fabric which warp and weft are not twisting.

\section{Fabric mechanical property parameters}

In order to get the mechanical performance of all kinds of silk fabrics, each kind of fabric are cut from $20 \mathrm{~cm}{ }^{*} 20 \mathrm{~cm}$ sample 3 pieces along the directions of the warp and weft. We make the experiment to test the mechanical properties of the 15 silk fabric samples respectively under low stress environment with automatic fabric style evaluation system KESFB-AUTO-A (Kawabata Evaluation System for Fabric system). KES-FB-AUTO-A instrument consists of KES-FB1 tensile and shearing tester, KES - FB2 pure bending tester, KES - FB3 compression tester, KES - FB4 friction and surface tester and other related data processing equipment [5]. The instrument used to measure the fabric tensile, shearing, bending, compression, friction, mechanical performance, physics properties index for a total of 16 under low stress environment. The test is done under the standard atmospheric condition.

\section{Tensile performance measurement}

The tensile performance parameters include work ratio WT (stretch to $500 \mathrm{gf} / \mathrm{cm}$ ), linearity LT (below the tensile curve area), recovery rate RT (the degree of tensile deformation energy recovery), elongation EMT (extend to the load of $500 \mathrm{gf} / \mathrm{cm}$ ). The tensile performance of the fabric reflects that the fabric deformation degree under stress. The draping and tensile of fabric under the gravity have obvious correlation. The tensile performance parameters are measured and listed in table 2.

\section{Bending and shearing performance testing}

The bending performance of the fabric describes the deformation of the warp direction or weft direction when the external force is acted on the fabric along the normal plane. It reflects the fabric softness, the shape and draping degree of the fabric. The bending performance parameters include the bending rigidity $\mathrm{B}$ and bending hysteresis $2 \mathrm{HB}$.

\begin{tabular}{|c|c|c|c|c|c|c|c|}
\hline \multicolumn{8}{|c|}{ FABRIC BASIC STRUCTURAL CHARACTERISTICS PARAMETERS } \\
\hline \multirow{2}{*}{$\begin{array}{c}\text { Sample } \\
\text { no. }\end{array}$} & \multirow[t]{2}{*}{ Sample name } & \multirow{2}{*}{$\begin{array}{l}\text { Organization } \\
\text { mode }\end{array}$} & \multicolumn{2}{|c|}{$\begin{array}{c}\text { Yarn linear density } \\
\text { (tex) }\end{array}$} & \multicolumn{2}{|c|}{$\begin{array}{c}\text { Density } \\
{\left[\text { root } \cdot(10 \mathrm{~cm})^{-1}\right]}\end{array}$} & \multirow{2}{*}{$\begin{array}{c}\text { Areal } \\
\text { density } \\
\left(\mathrm{g} \cdot \mathrm{m}^{-2}\right)\end{array}$} \\
\hline & & & Warp & Weft & Warp & Weft & \\
\hline 1 & Fancy crepe georgette & plain & 7.58 & 4.46 & 880 & 400 & 86.217 \\
\hline 2 & Silk spinning & twill & 3.81 & 17.80 & 410 & 600 & 95.883 \\
\hline 3 & Jianhong crepe & plain & 6.00 & 10.63 & 640 & 456 & 87.367 \\
\hline 4 & Sangbo satin & satin & 11.49 & 15.30 & 500 & 280 & 99.850 \\
\hline 5 & Hangluo & mixture & 3.69 & 6.55 & 480 & 400 & 69.400 \\
\hline 6 & Double palace & plain & 6.00 & 21.27 & 280 & 300 & 90.792 \\
\hline 7 & Shun weft satin & satin & 3.69 & 4.65 & 1020 & 380 & 52.750 \\
\hline 8 & Habotai & plain & 6.11 & 7.08 & 670 & 460 & 72.067 \\
\hline 9 & Silk taffeta & plain & 7.93 & 3.65 & 720 & 408 & 71.217 \\
\hline 10 & Plain crepe & satin & 2.96 & 3.95 & 530 & 410 & 67.650 \\
\hline 11 & Silk twill & twill & 5.80 & 7.25 & 560 & 410 & 60.300 \\
\hline 12 & Pearl satin & satin & 3.95 & 6.73 & 1402 & 438 & 70.333 \\
\hline 13 & crepe de chine & plain & 4.18 & 9.23 & 660 & 376 & 63.100 \\
\hline 14 & Heavy crepe & plain & 5.34 & 26.67 & 1550 & 470 & 202.800 \\
\hline 15 & Spun silk & plain & 12.23 & 13.58 & 520 & 268 & 98.425 \\
\hline
\end{tabular}


FABRIC TENSILE PERFORMANCE PARAMETERS

\begin{tabular}{|c|c|c|c|c|c|c|c|c|}
\hline \multirow{2}{*}{$\begin{array}{c}\text { Sample } \\
\text { no. }\end{array}$} & \multicolumn{2}{|c|}{ LT } & \multicolumn{2}{|c|}{$\begin{array}{c}W T \\
\left(g f \cdot m^{-2}\right)\end{array}$} & \multicolumn{2}{|c|}{$\begin{array}{l}\text { RT } \\
(\%)\end{array}$} & \multicolumn{2}{|c|}{$\begin{array}{l}\text { EMT } \\
(\%)\end{array}$} \\
\hline & warp & weft & warp & weft & warp & weft & warp & weft \\
\hline 1 & 0.447 & 0.393 & 8.717 & 13.183 & 64.627 & 56.507 & 7.800 & 13.420 \\
\hline 2 & 0.574 & 0.653 & 5.017 & 5.250 & 72.103 & 81.270 & 3.497 & 3.213 \\
\hline 3 & 0.468 & 0.456 & 13.033 & 16.583 & 60.873 & 44.613 & 11.143 & 14.633 \\
\hline 4 & 0.546 & 0.829 & 7.200 & 2.100 & 68.293 & 96.857 & 5.270 & 1.027 \\
\hline 5 & 0.608 & 0.666 & 6.233 & 4.950 & 66.323 & 64.997 & 4.107 & 2.980 \\
\hline 6 & 0.403 & 0.842 & 5.700 & 1.850 & 77.780 & 100.927 & 5.660 & 0.880 \\
\hline 7 & 0.600 & 0.323 & 2.733 & 14.183 & 94.550 & 48.057 & 1.823 & 17.570 \\
\hline 8 & 0.554 & 0.867 & 9.833 & 3.733 & 70.683 & 89.733 & 7.110 & 1.723 \\
\hline 9 & 0.819 & 0.799 & 2.417 & 4.000 & 86.980 & 85.423 & 1.180 & 2.003 \\
\hline 10 & 0.576 & 0.642 & 4.583 & 7.300 & 78.947 & 61.040 & 3.180 & 4.553 \\
\hline 11 & 0.691 & 0.576 & 2.250 & 4.233 & 96.313 & 82.730 & 1.303 & 2.943 \\
\hline 12 & 0.662 & 0.631 & 4.050 & 7.867 & 77.370 & 61.857 & 2.450 & 5.010 \\
\hline 13 & 0.523 & 0.480 & 14.400 & 13.017 & 65.053 & 47.370 & 11.013 & 10.853 \\
\hline 14 & 0.535 & 0.738 & 5.367 & 7.350 & 72.360 & 82.760 & 4.017 & 3.987 \\
\hline 15 & 0.444 & 0.663 & 5.367 & 12.467 & 79.510 & 42.910 & 4.837 & 7.527 \\
\hline
\end{tabular}

Table 3

\begin{tabular}{|c|c|c|c|c|c|c|c|c|c|c|}
\hline \multicolumn{11}{|c|}{ FABRIC SHEAR AND FLEXURAL PROPERTIES PARAMETER } \\
\hline \multirow{2}{*}{$\begin{array}{c}\text { Sample } \\
\text { no. }\end{array}$} & \multicolumn{2}{|c|}{$\begin{array}{c}G \\
(\mathrm{gf} / \mathrm{cm} \cdot \text { degree })\end{array}$} & \multicolumn{2}{|c|}{$\begin{array}{c}2 \mathrm{HG} \\
(\mathrm{gf} / \mathrm{cm})\end{array}$} & \multicolumn{2}{|c|}{$\begin{array}{c}2 \mathrm{HG5} \\
(\mathrm{gf} / \mathrm{cm})\end{array}$} & \multicolumn{2}{|c|}{$\begin{array}{c}\text { B } \\
\left(\mathrm{gf} \cdot \mathrm{cm} \cdot \mathrm{m}^{-2}\right)\end{array}$} & \multicolumn{2}{|c|}{$\begin{array}{c}2 \mathrm{HB} \\
\left(\mathrm{gf} \cdot \mathrm{cm} \cdot \mathrm{m}^{-2}\right)\end{array}$} \\
\hline & Warp & Weft & Warp & Weft & Warp & Weft & Warp & Weft & Warp & Weft \\
\hline 1 & 0.227 & 0.200 & 0.117 & 0.037 & 0.150 & 0.043 & 0.021 & 0.012 & 0.227 & 0.200 \\
\hline 2 & 0.303 & 0.237 & 0.260 & 0.053 & 0.427 & 0.130 & 0.014 & 0.038 & 0.303 & 0.237 \\
\hline 3 & 0.230 & 0.220 & 0.187 & 0.170 & 0.237 & 0.210 & 0.017 & 0.011 & 0.230 & 0.220 \\
\hline 4 & 0.257 & 0.283 & 0.120 & 0.053 & 0.503 & 0.393 & 0.045 & 0.160 & 0.257 & 0.283 \\
\hline 5 & 0.227 & 0.223 & 0.210 & 0.080 & 0.293 & 0.103 & 0.037 & 0.021 & 0.227 & 0.223 \\
\hline 6 & 0.230 & 0.250 & 0.160 & 0.053 & 0.267 & 0.160 & 0.017 & 0.202 & 0.230 & 0.250 \\
\hline 7 & 0.223 & 0.217 & 0.097 & 0.060 & 0.093 & 0.060 & 0.046 & 0.007 & 0.223 & 0.217 \\
\hline 8 & 0.230 & 0.260 & 0.037 & 0.017 & 0.303 & 0.260 & 0.019 & 0.063 & 0.230 & 0.260 \\
\hline 9 & 1.063 & 1.033 & 1.053 & 0.743 & 4.343 & 4.297 & 0.043 & 0.017 & 1.063 & 1.033 \\
\hline 10 & 0.227 & 0.210 & 0.110 & 0.037 & 0.180 & 0.070 & 0.032 & 0.010 & 0.227 & 0.210 \\
\hline 11 & 0.237 & 0.237 & 0.160 & 0.160 & 0.360 & 0.327 & 0.030 & 0.021 & 0.237 & 0.237 \\
\hline 12 & 0.243 & 0.253 & 0.237 & 0.070 & 0.460 & 0.230 & 0.050 & 0.019 & 0.243 & 0.253 \\
\hline 13 & 0.220 & 0.190 & 0.170 & 0.053 & 0.243 & 0.050 & 0.012 & 0.010 & 0.220 & 0.190 \\
\hline 14 & 0.303 & 0.243 & 0.170 & 0.050 & 0.453 & 0.213 & 0.101 & 0.304 & 0.303 & 0.243 \\
\hline 15 & 0.233 & 0.220 & 0.093 & 0.037 & 0.227 & 0.100 & 0.035 & 0.016 & 0.233 & 0.220 \\
\hline
\end{tabular}

The shearing performance of the fabric describes the deformation along the diagonal direction. It reflects the important properties of the fabric draping form related with the fabric surface modeling. Shearing performance parameters include the shearing stiffness G, Shear lag value of $2 \mathrm{HG}$, shear lag value $2 H G 5$. The bending and shearing performance parameters are tested and listed in table 3.
Compression, friction and surface performance testing

Fabric performance is a physical index used to reflect the fabric softness, the bearing capacity and comfortable, which has a close relationship among inherent quality, compression performance in thickness direction, fluffy fullness, the smoothness of the fabric surface, and etc. These parameters related with the 
THE COMPRESSION FRICTION AND SURFACE PERFORMANCE PARAMETERS

\begin{tabular}{|c|c|c|c|c|c|c|c|c|c|c|c|}
\hline \multirow{2}{*}{$\begin{array}{c}\text { Sample } \\
\text { no. }\end{array}$} & \multicolumn{2}{|c|}{ MIU } & \multicolumn{2}{|c|}{ MMD } & \multicolumn{2}{|c|}{$\begin{array}{c}\text { SMD } \\
\text { (u) }\end{array}$} & \multirow{2}{*}{ LC } & \multirow{2}{*}{$\begin{array}{c}\text { WC } \\
\left(\mathrm{gf} \cdot \mathrm{cm} \cdot \mathrm{m}^{-2}\right)\end{array}$} & \multirow{2}{*}{$\begin{array}{l}\text { RC } \\
(\%)\end{array}$} & \multirow{2}{*}{$\begin{array}{c}\text { T0 } \\
(\mathrm{mm})\end{array}$} & \multirow{2}{*}{$\begin{array}{c}\mathrm{Tm} \\
(\mathrm{mm})\end{array}$} \\
\hline & warp & weft & warp & weft & warp & weft & & & & & \\
\hline 1 & 0.116 & 0.178 & 0.007 & 0.010 & 1.435 & 4.377 & 0.601 & 0.092 & 64.102 & 0.361 & 0.300 \\
\hline 2 & 0.156 & 0.165 & 0.007 & 0.005 & 1.589 & 1.168 & 1.162 & 0.286 & 11429.860 & 0.304 & 0.205 \\
\hline 3 & 0.146 & 0.166 & 0.011 & 0.013 & 3.770 & 4.085 & 0.436 & 0.117 & 56.823 & 0.402 & 0.295 \\
\hline 4 & 0.125 & 0.163 & 0.006 & 0.008 & 5.818 & 1.749 & 0.500 & 0.065 & 58.058 & 0.297 & 0.236 \\
\hline 5 & 0.124 & 0.189 & 0.015 & 0.011 & 3.267 & 2.871 & 0.507 & 0.101 & 57.999 & 0.308 & 0.227 \\
\hline 6 & 0.131 & 0.184 & 0.016 & 0.008 & 7.439 & 2.002 & 0.516 & 0.065 & 53.302 & 0.246 & 0.194 \\
\hline 7 & 0.106 & 0.154 & 0.004 & 0.008 & 1.366 & 3.082 & 0.468 & 0.203 & 68.428 & 0.373 & 0.200 \\
\hline 8 & 0.113 & 0.127 & 0.008 & 0.009 & 1.267 & 1.672 & 0.431 & 0.061 & 54.062 & 0.224 & 0.167 \\
\hline 9 & 0.121 & 0.137 & 0.022 & 0.009 & 0.944 & 1.940 & 0.578 & 0.046 & 62.473 & 0.166 & 0.134 \\
\hline 10 & 0.124 & 0.198 & 0.003 & 0.005 & 0.571 & 1.792 & 0.562 & 0.065 & 58.321 & 0.217 & 0.171 \\
\hline 11 & 0.164 & 0.166 & 0.006 & 0.005 & 0.712 & 0.735 & 0.669 & 0.047 & 63.707 & 0.154 & 0.126 \\
\hline 12 & 0.106 & 0.158 & 0.003 & 0.006 & 2.256 & 1.859 & 0.543 & 0.077 & 60.836 & 0.258 & 0.202 \\
\hline 13 & 0.116 & 0.170 & 0.010 & 0.008 & 3.304 & 2.689 & 0.514 & 0.086 & 62.812 & 0.308 & 0.241 \\
\hline 14 & 0.158 & 0.133 & 0.009 & 0.005 & 7.051 & 1.936 & 0.322 & 0.136 & 52.701 & 0.615 & 0.445 \\
\hline 15 & 0.129 & 0.195 & 0.008 & 0.010 & 6.088 & 3.256 & 0.519 & 0.065 & 56.891 & 0.278 & 0.227 \\
\hline
\end{tabular}

three performances have influence on the fabric draping form. They include the compression ratio WC, compression recovery rate $\mathrm{RC}$, linear compression degree LC, the thickness of the fabric T0, stable thickness Tm. The compression performance parameters of different fabrics are tested and listed in table 4.

The friction and surface performance of the fabric reflects the friction between the fabric and the other objects. It has major influence on the hand feel of the fabric. Friction and surface performance have relation with the smoothness of the fabric surface. The smoothness has a certain influence on the friction of the fabric itself. The friction and surface performance parameters include dynamic friction coefficient MIU, the friction coefficient of mean deviation MMD, surface roughness of SMD. All these parameters are tested and listed in table 4.

\section{Draping performance testing}

In this paper, YG811-F is used to test the drapability parameters; it is a knitting fabric draping testing instrument. The evaluation indexes of fabric mainly include drape coefficient and active rate. Among these, drape coefficient is used to measure the drape form of static fabric; the other is used to describe the dynamic drape properties of fabrics.

The drape coefficient can be computed with the following formula:

$$
F=\frac{A_{F}-A_{d}}{A_{D}-A_{d}} \times 100(\%)
$$

Where, $A_{F}$ is the projected area of the sample, $A_{D}-$ the area of the sample, and $A_{d}$ - the area of the tester disc. It can be derived that the bigger the drape coefficient is, the harder the fabric is and the worse drapability of the fabric is.
The active rate can be computed with the following formula:

$$
A=\frac{X_{s}-X_{D}}{1-X_{s}}
$$

Where, $X_{s}$ is the static drape index, $X_{D}$ - the dynamic drape index.

Fabric drapability includes two indicators about the trailer degree and trailer form. Trailer degree refers to the fabric degree of free boundary prolapse only with gravity. According to the national standard GB/T233292009 textile fabric drape measurement, measurement device is shown in figure 1. It is usually using draping coefficient $F$ to indicate the degree of fabric draping. Draping form mainly refers to the three dimensional surface shape. Due to the anisotropy of the fabric, the three dimensional shape of the fabric has the effect of asymmetry. The actual process, generally represented by the corrugated profile curve drape expanded view [6-7]. Specifically,

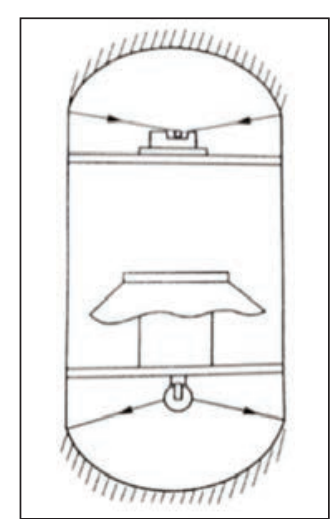

Fig. 1. YG811 fabrics drape tester the fabric shape is usually described with draping wave, maximum amplitude, minimum amplitude, the average amplitude.

The sample is cut to be a diameter of $24 \mathrm{~cm}$ circular specimen. Testing is done under standard atmospheric conditions (as shown in figure 2), that is in static and with the speed $40 \mathrm{r} / \mathrm{min}$ respectively. The performance parameters include static draping coefficient F0, dynamical 


\begin{tabular}{|c|c|c|c|c|c|c|}
\hline \multicolumn{7}{|c|}{ FABRIC DRAPING PERFORMANCE PARAMETERS } \\
\hline Sample no. & $\begin{array}{c}\text { Static wave } \\
\text { number, N0 }\end{array}$ & $\begin{array}{c}\text { Static drape } \\
\text { coefficient, F0 }\end{array}$ & $\begin{array}{c}\text { Dynamic wave } \\
\text { number, N1 }\end{array}$ & $\begin{array}{c}\text { 40r/min Dynamic } \\
\text { Wave number, F1 } \\
(\%)\end{array}$ & $\begin{array}{c}\text { Stiffness, Y } \\
(\%)\end{array}$ & $\begin{array}{c}\text { Aesthetic } \\
\text { coefficient, Ac } \\
(\%)\end{array}$ \\
\hline 1 & 6 & 58.25 & 6 & 62.52 & 63.58 & 21.93 \\
\hline 2 & 4 & 47.51 & 5 & 51.51 & 55.93 & 13.71 \\
\hline 3 & 6 & 28.46 & 6 & 32.10 & 35.66 & 10.43 \\
\hline 4 & 3 & 50.31 & 3 & 54.03 & 58.42 & 7.91 \\
\hline 5 & 4 & 38.24 & 5 & 42.54 & 46.62 & 11.79 \\
\hline 6 & 3 & 50.69 & 4 & 55.27 & 59.40 & 10.74 \\
\hline 7 & 5 & 36.57 & 5 & 40.79 & 45.55 & 10.54 \\
\hline 8 & 6 & 42.66 & 6 & 48.12 & 52.88 & 14.19 \\
\hline 9 & 2 & 64.01 & 2 & 64.94 & 68.67 & 5.75 \\
\hline 10 & 5 & 29.28 & 5 & 32.98 & 35.95 & 9.59 \\
\hline 11 & 5 & 43.36 & 6 & 48.12 & 52.82 & 13.21 \\
\hline 12 & 5 & 37.07 & 5 & 41.96 & 45.89 & 12.29 \\
\hline 13 & 6 & 26.17 & 6 & 32.28 & 35.96 & 10.64 \\
\hline 14 & 3 & 53.51 & 3 & 56.34 & 60.31 & 8.70 \\
\hline 15 & 5 & 32.07 & 5 & 36.80 & 40.80 & 10.03 \\
\hline
\end{tabular}

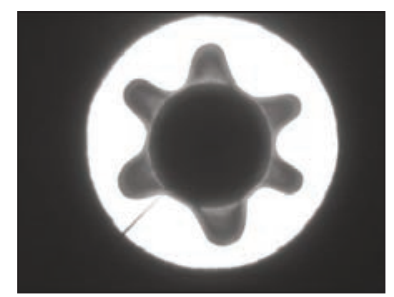

a

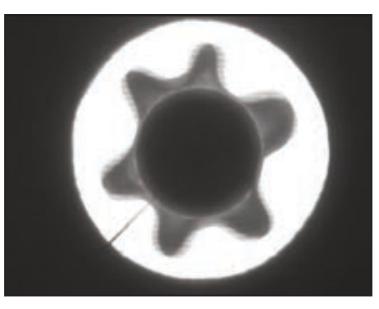

b
Fig. 2. Sample 3: $a$ - static drape figure; $b-40 \mathrm{r} / \mathrm{min}$ dynamic drape figure

draping coefficient $F 1$, static wave number $N$ (unit is a). The draping performance parameters are tested and listed in table 5.

\section{EXPERIMENTAL DATA PROCESSING}

\section{Correlation analysis}

In this paper, the correlation analysis is done with the testing data listed in table 1 to table 5 . Correlation analysis is often used to analyse the correlation factors of the variables to measure the degree of correlation among the different variables. The idea of the correlation analysis is to get correlation coefficient matrix by calculating the co-variance matrix of sequence. The correlation coefficients describe the strength and direction of the linear relationship between the two random variables, then through the correlation coefficient to determine the correlation between parameters.

At present, the fabric draping coefficient is used to describe the degree of fabric draping, that is the draping coefficient smaller, the better the draping. In our experiment, we need to get real silk fabric index on the direction of mechanics and structure, and the interrelation between the real silk fabric draping. By measuring basic parameters and mechanical performance parameters, then we use more dynamic drape indexes. There are 40 kinds of parameters to represent a silk fabric and make a sequence of these parameters. We make the correlation analysis with the sequence.

Firstly, every kind of fabric samples of the test indexes are formed to be a sequence, each column $\mathbf{X}_{i}=\left(x_{1}, x_{2}, \ldots, x_{15}\right)^{T}$ is composed with each kind of performance parameters of 15 kinds of samples, for the convenience of calculation, we classify the first column $\mathrm{X}_{1}$ for fabric dynamic drape coefficient $F 1$.

With the sequence $\mathbf{X}$, the tested data of different samples are inconsistent, so first step of data processing is to standardize the indicators. The original tested data are dimensionless index evaluation values, these data must have the same order, so that the indicators should be compared and processed. Commonly data standardization method is used to complete the procedure such as min-max standardization and Z-score standardization. In the paper Z-score standardization is used. Each column sequence is transformed with the following equation:

$$
y_{i}=\frac{x_{i}-\mu}{\sigma}
$$

The $y_{i}$ equals to dimensionless values which resulted form the original data $x_{i}$ standardization. $\mu$ is the average of each kind of data, $\sigma$ - the standard deviation of all the data. After the original data sequence $X$ is processed, the corresponding normalized sequence $\mathbf{Y}=\left(\mathrm{Y}_{1}, \mathrm{Y}_{2}, \mathrm{Y}_{3}, \ldots, \mathrm{Y}_{n}\right)$ is obtained. After this processing sequence of each column of the index parameter of the mean to 0 , variance is 1 . Then through the calculation of co-variance matrix of a 


\begin{tabular}{|c|c|c|c|c|c|c|c|c|c|c|}
\hline \multicolumn{11}{|c|}{ THE CORRELATION COEFFICIENT COMPARISON WITH F1 } \\
\hline $\begin{array}{l}\text { Contrast } \\
\text { index } \\
\text { with F1 }\end{array}$ & Y & F0 & $\begin{array}{c}\mathrm{RT} \\
\text { latitude }\end{array}$ & No & N1 & $\begin{array}{c}\text { WT } \\
\text { latitude }\end{array}$ & longitude & $\underset{\text { latitude }}{\mathrm{G}}$ & $\begin{array}{c}2 \mathrm{HG} 5 \\
\text { longitude }\end{array}$ & $\begin{array}{l}2 \mathrm{HG} 5 \\
\text { latitude }\end{array}$ \\
\hline$|r|$ & 0.996 & 0.996 & 0.683 & 0.605 & 0.566 & 0.518 & 0.516 & 0.513 & 0.503 & 0.493 \\
\hline $\begin{array}{c}\text { Contrast } \\
\text { index } \\
\text { with F1 }\end{array}$ & $\begin{array}{c}2 \mathrm{HB} \\
\text { longitude }\end{array}$ & $\begin{array}{c}2 \mathrm{HG} \\
\text { longitude }\end{array}$ & $\begin{array}{c}\text { B } \\
\text { latitude }\end{array}$ & $\begin{array}{c}2 \mathrm{HB} \\
\text { latitude }\end{array}$ & $\begin{array}{c}\text { MIU } \\
\text { latitude }\end{array}$ & $\begin{array}{c}2 \mathrm{HG} \\
\text { latitude }\end{array}$ & $\begin{array}{c}\text { EMT } \\
\text { latitude }\end{array}$ & $\begin{array}{c}\mathrm{LT} \\
\text { latitude }\end{array}$ & $\begin{array}{c}\text { MMD } \\
\text { longitude }\end{array}$ & $\begin{array}{c}\text { WT } \\
\text { longitude }\end{array}$ \\
\hline$|r|$ & 0.459 & 0.453 & 0.434 & 0.434 & 0.420 & 0.402 & 0.397 & 0.394 & 0.388 & 0.361 \\
\hline $\begin{array}{c}\text { contrast } \\
\text { index } \\
\text { with F1 }\end{array}$ & $\mathrm{D}$ & $\begin{array}{c}\text { EMT } \\
\text { longitude }\end{array}$ & $\begin{array}{c}\mathrm{T} \\
\text { longitude }\end{array}$ & $\begin{array}{c}\mathrm{B} \\
\text { longitude }\end{array}$ & $\begin{array}{c}\mathrm{T} \\
\text { latitude }\end{array}$ & $\begin{array}{c}\mathrm{LT} \\
\text { longitude }\end{array}$ & $\begin{array}{l}\text { SMD } \\
\text { latitude }\end{array}$ & LC & Ac & $\mathrm{RC}$ \\
\hline$|r|$ & 0.332 & 0.321 & 0.294 & 0.255 & 0.223 & 0.210 & 0.204 & 0.159 & 0.158 & 0.124 \\
\hline $\begin{array}{c}\text { Contrast } \\
\text { index } \\
\text { with F1 }\end{array}$ & $\begin{array}{c}\text { MIU } \\
\text { longitude }\end{array}$ & $\begin{array}{c}\mathrm{S} \\
\text { longitude }\end{array}$ & $\begin{array}{c}\mathrm{RT} \\
\text { longitude }\end{array}$ & $\begin{array}{c}\text { MMD } \\
\text { latitude }\end{array}$ & $\mathrm{Tm}$ & $\underset{\text { latitude }}{\mathrm{S}}$ & $\begin{array}{c}\text { SMD } \\
\text { longitude }\end{array}$ & WC & T0 & \\
\hline$|r|$ & 0.121 & 0.112 & 0.109 & 0.099 & 0.073 & 0.063 & 0.062 & 0.028 & 0.015 & \\
\hline
\end{tabular}

standardized sequence $\mathbf{Y}$, getting the correlation coefficient matrix $R$ :

$$
\begin{aligned}
R & =\left(\begin{array}{cccc}
\operatorname{Cov}\left(Y_{1}, Y_{1}\right) & \operatorname{Cov}\left(Y_{1}, Y_{2}\right) & \ldots & \operatorname{Cov}\left(Y_{1}, Y_{40}\right) \\
\operatorname{Cov}\left(Y_{2}, Y_{1}\right) & \operatorname{Cov}\left(Y_{2}, Y_{2}\right) & \ldots & \operatorname{Cov}\left(Y_{2}, Y_{40}\right) \\
\vdots & \vdots & \ddots & \vdots \\
\operatorname{Cov}\left(Y_{40}, Y_{1}\right) & \operatorname{Cov}\left(Y_{40}, Y_{2}\right) & \ldots & \operatorname{Cov}\left(Y_{30}, Y_{40}\right)
\end{array}\right)= \\
& =\left(\begin{array}{cccc}
r_{1,1} & r_{1,2} & \ldots & r_{1,40} \\
r_{2,1} & r_{2,2} & \ldots & r_{2,40} \\
\vdots & \vdots & \ddots & \vdots \\
r_{40,1} & r_{40,2} & \ldots & r_{40,40}
\end{array}\right)
\end{aligned}
$$

In the formula, $Y=\left(Y_{1}, Y_{2}, Y_{3}, \ldots, Y_{n}\right)$ is the standardized sequence $\mathbf{X}$, in accordance with the preceding specified in the first column $X_{1}$ for the fabric of the dynamic drape coefficient $F 1$, then $Y_{1}$ is the standardized dynamical draping coefficient. $r_{i, j}=\operatorname{Cov}\left(Y_{i}, Y_{j}\right)$ is the co-variance of the column $i$ and the column $j$, that is also called the correlation coefficient, which reflects the strength of the correlation between the two columns attributes.

The following step is to select the first row of the correlation coefficient matrix $R$, each of the correlation coefficient $r$ indicate the strength of the correlation between the dynamic draping coefficient of fabric $F 1$ index and other indicators, in $r_{1,1}=1$. According to the correlation coefficient of the absolute value size, the absolute value of related coefficient $r_{i, j}$ is got and has the following relationship comparison shown in table 6 .

\section{Result analysis}

The table above gives the correlation coefficient between the experimental dynamical draping coefficient and other parameters. The data are indexes which are used to measure linear correlation between the variables, the range of $r$ is between $[-1,1]$. When $r=0, \mathrm{X}, \mathrm{Y}$ are not related; when $|r|=1, \mathrm{X}, \mathrm{Y}$ is completely related. We can conclude that $X$ and $Y$ have a linear functional relationship. The change of $X$ leads the change of $Y$ partially. At the same time, the absolute value of $r$ is greater; the change of $Y$ is greater. When $|r|>0.8, \mathrm{X}$ and $\mathrm{Y}$ are highly correlated. When $|r|<0.3, \mathrm{X}$ and $\mathrm{Y}$ are lowly correlated.

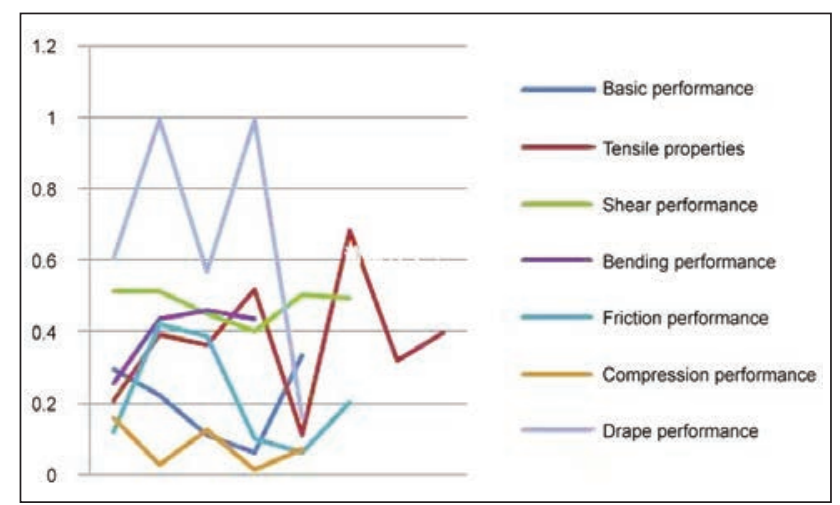

Fig. 3. Correlation between the various indicators and dynamic drape of fabric

From the above table 6 and figure 3, we can conclude: the silk fabric dynamic draping performance and representative fabric compression performance indexes (LC, RC, WC, TO, Tm), the friction and surface performance indexes (MIU, MMD, SMD) and fabric density index (S) related to small, and the representative of the fabric static drape indexes (F0), the weft tensile performance indexes (RT weft, WT weft, LT weft, EMT weft) and the bending and shearing performance indexes (G, $2 \mathrm{HG}$, 2HG, B, $2 \mathrm{HB}$ ) have strong correlation.

Among them, the warp fabric tensile performance indexes (RT warp, WT warp, LT warp, EMT warp) have a lower correlation with the fabric dynamical draping performance, however the weft tensile performance indexes (RT warp and WT warp, LT warp, EMT warp) have a higher correlation with the fabric dynamical draping performance. The result shows that warp direction and weft direction of the silk fabric have more influence on the drapability. 
Comparing fabric No. 11 sample and fabric sample No. 14, which is the same spun silk of two kinds of fabric drape, the drape coefficient of spun silk twill No. 14 is larger, the drape of spun silk twill is obviously better than plain weave silk. The same twill drape no. 13 is better than the same kind of Silk

\section{CONCLUSION}

Fabric draping performance is one of the important factors which influence the fabric appearance and hand feel. Silk fabric has better draping performance, so the researcher always gives priority to material. By measuring the parameters of real silk fabrics, we can make a comprehensive evaluation of the influence of various parameters on the fabric drape. This provides a basis for our further research on fabric dynamic simulation.

We can get the following conclusion from experiment in this paper:

- The weft tensile property index of real silk fabric has a great influence on the degree of dynamical draping, and the next ones are the shearing performance indexes and the bending performance indexes. Friction performance indexes, compression performance indexes of weft tensile performance indexes of real silk fabrics and fabric density have little effect on dynamical draping.

- The most of the absolute value of correlation coefficient between 0.3 to 0.5 , the parameters that affect the real silk fabric dynamical drape should be multifarious.

- The most relevant index with dynamic drapability is static drapability of silk fabric. This is similar to our understanding of fabric.

- Twill silk spinning class silk fabric dynamical draping is superior to plain spun silk fabrics, satin silk fabric dynamical draping is better than plain silk fabrics. This is consistent with our daily experience. The results prove the validity of our experiment.

- The next job is to treat analysis in the paper which influence the parameters of the fabric draping, and establish mathematical model to provide theoretical basis for the fabric draping model and dynamical simulation.

\section{ACKNOWLEDGMENTS}

The research is funded by Team plan of scientific and technological innovation of outstanding youth in universities of Hubei province (T201807).

\title{
REFERENCES
}

[1] Zhigui, L., Wei, F., Weizhi, H., Evaluation and analysis of fabric suspension performance based on support vector machine, 2009

[2] Qiang, L., Yuqing, G., Feng, J., Based on look up projection method of fabric drape test, In: Textile Journal, 2008, 3

[3] Guo, H., Zhao, W., Comparison of Bamboo Knitted Fabric Dynamic Drapability and Correlation Analysis of Its Influencing factors, In: Guangxi Textile Science\&Technology, 2010, 39

[4] Longyan, J., The fabric drape performance comparison, In: Journal of silk, 2001, 7, 28-30

[5] Jun, X., Xiaowen, J., Mu, Y., Drape aesthetics and to discuss the relationship between fabric structural characteristics, In: Journal of northwest of textile engineering, 1999, 13, 3, 256-258

[6] Girneata, A., Giurgiu, A., Dobrin, O.C., et al., Performance management practices in Romanian textile and clothing companies, In: Industria Textila, 2015, 66, 2, 108-113

[7] Yongping, G., Changlong, L., Ruqin, L., Theory of fabric drape and testing methods research review, In: Journal of China textile university, 1999, 25, 3, 94

\section{Authors:}

XINRONG HU, TAO PENG, JUNPING LIU, GANG LI, SHUQIN CUI, JUNJIE ZHANG, RUHAN HE, MIN LI, JIA CHEN

Engineering Research Center of Hubei Province for Clothing Information, School of Mathematics\&Computer Science,

Wuhan Textile University Wuhan, Hubei, 430074, China

\author{
Corresponding author: \\ TAO PENG \\ e-mail: 33097696@qq.com \\ JUNJIE ZHANG \\ e-mail: 2007086@wtu.edu.cn
}

